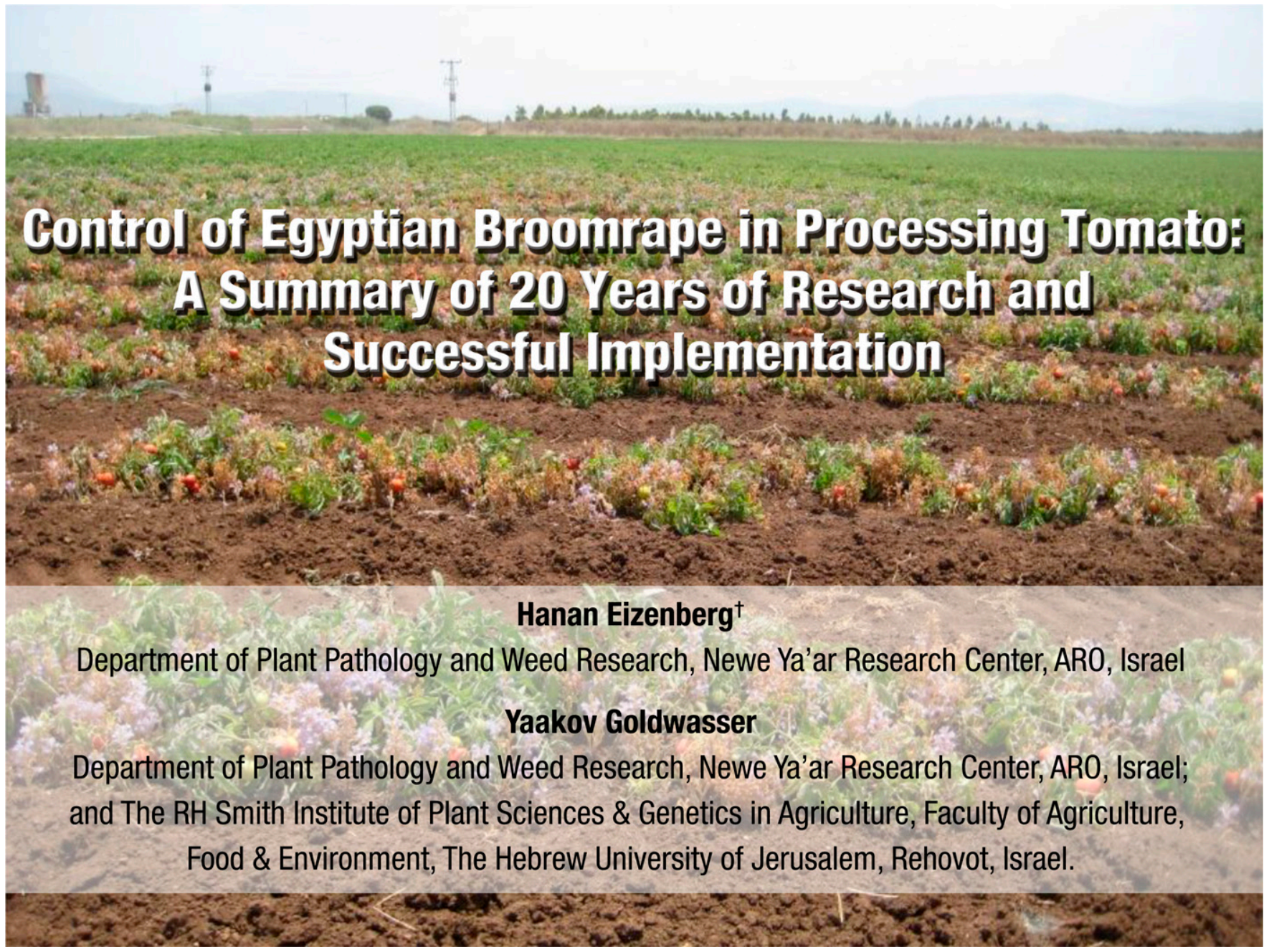

The obligate root parasitic weeds commonly known as broomrape (Orobanche and Phelipanche spp.) cause severe damage to vegetable and field crops worldwide. Efficient control of these parasites is difficult due to their development and attachment to the host plant (via a specialized organ, the haustorium) under the soil surface and to their unique biological traits of massive seed production, facile seed dispersal, germination only under specific conditions, and seed longevity. The major damage inflicted by the parasites takes place underground, making control extremely challenging. Egyptian broomrape (Phelipanche aegyptiaca) is a devastating pest in the Mediterranean basin, parasitizing a wide host crop range, including tomato, sunflower, legumes, and carrot, resulting in severe crop losses. Twenty years of research have led to the development of integrated smart management strategies for combating this parasite in processing tomato fields. In particular, an explicit decision support system (DSS) designated PICKIT has been developed; this DSS is based on predicting parasitism dynamics and employing a range of selective targeted chemical applications (preplanting incorporation, foliar application, and herbigation). In this feature article, we describe the evolution of this research

${ }^{\dagger}$ Corresponding author: H. Eizenberg; E-mail: eizenber@volcani.agri.gov.il

Funding: The Chief Scientist of the Israel Ministry of Agriculture and The Israel Vegetable Growers Association (grant no. 132-1499-16) and 'Netafim.

Accepted for publication 7 March 2018.

(C) 2018 The American Phytopathological Society from the laboratory, through greenhouse and experimental field trials, to large scale commercial fields and the successful assimilation of PICKIT into agricultural practice. The use of PICKIT in fields of processing tomatoes in northern Israel has led to effective control of Egyptian broomrape, even in fields with high infestation levels, resulting in a tomato yield increase of an average of 40 tons $\mathrm{ha}^{-1}$ compared with nontreated plots. In 2016, PICKIT was commercially implemented in 33 fields, totaling 400 ha, giving 95\% Egyptian broomrape control and tomato yields of 115 to 145 tons $\mathrm{ha}^{-1}$. The outcome of this research is now enabling farmers to grow tomatoes in Egyptian broomrapeinfested fields with assured increased yields and hence high profits.

\section{Parasitic Plants}

Parasitic plants grow on all the continents of the globe, excluding Antarctica, and account for approximately $1 \%$ of 260,000 angiosperm species in 28 dicotyledonous plant families. Recently, the families of parasitic plants have been rearranged into 12 orders, based on molecular studies indicating that parasitism has evolved independently several times (Heide-Jørgensen 2013). Although some parasitic plants were mentioned in writings predating the Common Era (by Theophrastus, 372 to $287 \mathrm{BCE}$ ), these plants did not attract interest until the 19th century, and only in the 1950s was intensive research on these plants initiated, following an infestation of Striga asiatica in maize fields in the eastern U.S.A. (Heide-Jørgensen 2013). Presently, several parasitic species, recognized as important agricultural weeds, infest a wide range of crops around the globe, resulting in serious crop and income losses and hence posing a major threat to the food security of numerous communities (Goldwasser and Kleifeld 2004; Parker 2013). 
The principal organ that characterizes parasitism in all parasitic plants is the "haustorium," which attaches to, invades, and fuses into the host xylem and phloem conductive systems and enables the parasite to extract water and nutrients from the host plant (Joel 2013; Parker and Riches 1993). Parasitic plants can be classified according to the host plant organ to which they connect (tree and shrub aerial shoot parasites, shoot parasites, and root parasites) with agriculturally important parasitic weeds being classified into four main groups:

Viscaceae and Loranthaceae (mistletoes): green hemiparasites that parasitize aerial parts of shrubs and trees;

Cuscutaceae (dodders): holoparasitic twining stem parasites that attack mainly dicot plants;

Orobanchaceae (figworts and witch weeds previously classified as Scrophulariaceae): hemiparasitic root parasites that invade roots of host plants;

Orobanchaceae (broomrapes): holo-parasitic root parasites that invade dicot plants.

\section{Broomrapes}

Most Orobanchaceae species are of no economic importance, but the weedy broomrapes are root parasites that cause devastating damage to agricultural crops. Taxonomically, the weedy broomrapes can be classified into two holoparasitic genera, Orobanche and Phelipanche, according to morphological and karyological criteria and to molecular phylogenetics (Joel 2009; Schneeweiss et al. 2004). Botanically, Orobanche species are characterized by unbranched inflorescence stems and the lack of bracteoles, while in Phelipanche species, the inflorescence stems are branched and bear bracteoles (Parker 2013). Some of the Orobanchaceae species have adapted to agricultural practices and have become a major threat to crop production. Moreover, crop losses are expected to increase due to a predicted rise in infestation levels and an expansion of the global distribution of the weedy Orobanchaceae plant parasite species into new agricultural regions as a result of the extensive global trade in agricultural goods and global warming.

Seven broomrape species belonging to Orobanche and Phelipanche are considered to be of agricultural importance (Parker 2013):

1. Crenate broomrape (O. crenata) is a major plant parasite that infests a wide range of crops, mainly species belonging to the Fabaceae and Apiaceae and some hosts belonging to the Curcurbitaceae, Solanaceae, Lamiaceae, Ranunculaceae, and Asteraceae. The parasite is distributed around the Mediterranean and in the Near East, western Asia, Sudan, and Ethiopia.

2. Small broomrape (O. minor) infests a very wide host range, including species of the Fabaceae, Solanaceae, Ateraceae, and Apiaceae. O. minor is an important pest in clover and lucerne seed production but has a lesser impact on other susceptible crops.

3. Foetid broomrape (O. foetida) attacks a wide range of species restricted to the Fabaceae. Its distribution is limited to North Africa, Spain, Portugal, and the Balearic Islands. It has been reported to be a problem in faba bean cultivation and also, but to a lesser extent, in chickpea and vetch crops in Tunisia.

4. Sunflower broomrape (O. cumana) is specific to sunflower alone affecting the production of oil and confectionary seeds. This species is distributed in southeast Europe, the Middle East, Southwest Asia, Spain, and China, and heavy yield losses have been reported in infested areas in these regions.

5. Nodding broomrape (O. cernua) attacks mainly Solanaceae crops; it constitutes a severe problem in tomato fields in southern Europe and Africa and in tobacco fields in India.

6. Branched broomrape (P. ramosa) affects an extremely wide range of host crops belonging to the Solanaceae, Brassicaceae, Cannabaceae, Fabaceae, Apiaceae, and Asteraceae. It is distributed in Europe, the Middle East, West Asia, North
Africa, Ethiopia, Somalia, and Australia. High yield losses have been reported mainly in tomato, tobacco, and rapeseed.

7. Egyptian broomrape (P. aegyptiaca) has a similar host range to branched broomrape but infests a wider range of Brassicaceae and Curcurbitaceae species. Its distribution is similar to that of branched broomrape, but it extends further to South Asia and China. Severe damage has been reported to tomato (Fig. 1), potato, lentil, and carrot crops.

A glossary of terms used in this feature article is given in Box 1 . Egyptian Broomrape Life Cycle

The Egyptian broomrape lifecycle is particularly specific for holoparasitism. The minute seeds $(0.2$ to $0.4 \mathrm{~mm})$ germinate in the rhizosphere only after being exposed to a preconditioning period of a few days of moist and warm conditions. In addition, the seeds of this obligate parasite germinate only in response to specific plant-derived germination stimulants released by the roots of specific host plants. These stimulants have been identified only recently in root exudates, and most belong to the group of plant hormones known as strigolactones, which include orobanchol, didehydroorobanchol, and solanacol (Fernández-Aparicio et al. 2011, 2016; Screpanti et al. 2016, Yoneyama et al. 2013; Zwanenburg and Pospísil 2013). These very specific prerequisite conditions ensure that only seeds within the rhizosphere of an appropriate host plant root will germinate.

Following the induction of germination, the radicle of the parasite seedling grows rapidly, but only to a few millimeters in length, and will exhaust its limited energy reserves within a few days of germination if it does not make contact with a host plant root. Following contact with the host root, the radicle forms a haustorium, a specialized organ common to parasitic plants that invades host tissues and ultimately fuses into the root vascular system. It then serves as a structural and physiological bridge facilitating withdrawal of water and nutrients from the conductive systems of the host plant (Joel 2013; Kuijt 1977; Musselman 1980; Pérez-de-Luque et al. 2005). Following the accumulation of metabolites, the parasite develops a tubercle, which absorbs and stores nutrients and water. The mature tubercle then develops a branched shoot that emerges above the soil surface and develops numerous flowers (Fig. 2). Following pollination of the flowers, the plant produces many capsules, yielding hundreds of thousands of seeds per plant, which remain viable in the soil for many years (Foy et al. 1989; Holm et al. 1977; Pieterse 1979) (Fig. 3).

At all stages of the parasite life cycle, temperature is the most important factor in its development, with a strong interdependence between parasitism dynamics and temperature being reported for several parasite-crop interactions, namely: small broomrape in red clover (Eizenberg et al. 2004a); sunflower broomrape in sunflower (Castejon-Muñoz et al. 1993; Ephrath and Eizenberg 2010); Egyptian broomrape in tomato (Ephrath et al. 2012), carrot (Cochavi et al. 2016), and potato (Hosseini et al. 2017); and crenate broomrape in faba bean, grass pea, and lentil (Mesa-García and García-Torres 1986; Pérez-de-Luque et al. 2016). The role of temperature in crop development, like that in parasite development, has also been well documented (Finch-Savage et al. 1998). The strong links between temperature, parasite development, and crop development have thus been utilized for the development of the thermal time models for predicting parasitism dynamics and optimizing the chemical control of root parasitic weeds, as described later in this review.

\section{Broomrape Management}

Broomrape species are very difficult to control, with the problems of managing these parasitic weeds being a function of their life cycle. As mentioned above, germination requirements include specific temperature and moisture conditions below ground in concert with specific host plant root germination exudate signals. Following germination, the parasite remains concealed underground for the major part of its life, thus being inaccessible to conventional agricultural control methods, such as tillage and contact herbicides. When the 
parasite finally emerges above ground, the majority of the damage to the host has already been done, and control would be ineffective. The late appearance of parasite shoots above ground and the lack of a photosynthetic system as a potential herbicide target make broomrape species extremely difficult to control by conventional herbicide management strategies. The problem is exacerbated by the seed traits-vast amounts of seeds are produced and these exhibit prolonged longevity in the soil (Eizenberg at al. 2013) (Fig. 3). Furthermore, the minute seeds are easily dispersed to close and distant fields by wind, water, livestock and, particularly, human agricultural practices. Such practices include the use of contaminated agricultural vehicles, farm implements, and produce containers as well as the transportation of contaminated plant material (crop seeds and hay) and of contaminated soil and manure (Goldwasser and Rodenburg 2013; Yaacoby et al. 2015). Broomrape

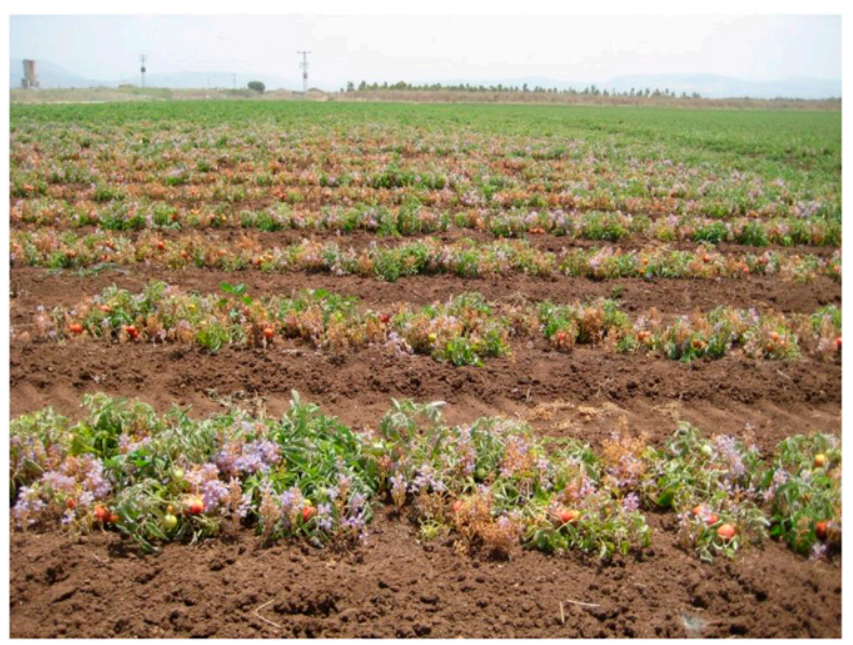

Fig. 1. A processing tomato field in northern Israel heavily infested with Egyptian broomrape. management must therefore comprise a wide range of control methods, including prevention, cultural, chemical, and biological control, hand weeding, and exploitation of crop resistance (by the use of genetically modified parasite-resistant and herbicide-resistant crops) (Hershenhorn et al. 2009). Among these methods, we will focus here on chemical control.

Chemical control of broomrape rests on a variety of herbicide application methods: soil fumigation; preplanting, preplanting incorporated and postplanting herbicide applications; and chemigation with herbicides (herbigation) through sprinkler, drip, linear, or center pivot irrigation systems. Soil fumigants can be effective in broomrape seed eradication, but they usually require precise, costly, and complex application methods and pose a toxicity threat to humans and the environment. In the past, soil fumigation with methyl bromide was found to be extremely efficient in broomrape seed control (Kleifeld et al. 1987), but this herbicide has been banned because of its impact on the environment, and the alternatives, such as metham sodium compounds (Goldwasser et al. 1995), are not as effective.

In view of the lack of a photosynthetic system in broomrape, two main types of herbicide have been tested for weed control- the aromatic amino acid synthesis inhibitor, glyphosate, and inhibitors of acetolactate synthase (ALS; an enzyme involved in the biosynthesis of branched-chain amino acids), namely, sulfonylureas and imidazolinones (Little and Shaner 1991). The control outcome of these chemicals from the beginning of the 1970s has been reviewed by Eizenberg et al. (2013). The control strategy for these herbicides is to spray them onto the plant foliage, usually in two to three applications in low dosages so as to ensure both crop selectivity and, at the same time, rapid acropetal and basipetal translocation. This translocation leads to lethal accumulation of the herbicide in the attached parasite, which acts as a strong metabolic sink. This strategy has been used for applying glyphosate to control Egyptian and crenate broomrape parasitizing parsley, faba bean, carrot, and pea. It has also been used for the application of imazapic to control sunflower and Egyptian broomrape parasitizing sunflower; imazethapyr to control crenate broomrape in faba bean; imazamox to control small

\section{BOX 1}

Glossary

ALS inhibiting herbicides - Herbicides that inhibit acetolactate synthase (ALS), the common enzyme in the biosynthesis of the branched-chain amino acids, valine, leucine, and isoleucine

CHEM - Chemigation, application of chemicals via irrigation systems

DAP - Days after planting

DAT - Days after treatment

DSS - Decision support system

EB - Egyptian broomrape (Phelipanche aegyptiaca)

GDD - Growing degree days

Haustorium - A special organ of parasitic plants that invades host plant tissues and serves as a structural and physiological bridge, enabling the transfer of water and nutrients from the host plant to the parasite

Herbigation - Application of herbicides via irrigation systems

Holoparasite - A parasite that has no photosynthetic abilities and is exclusively dependent on its host to complete its life cycle Imidazolinone herbicides - A subgroup of the ALS-inhibiting herbicides composed of a heterocyclic ketones derived from imidazoline LC/MSMS - Analytical chemistry technique in which liquid chromatography is followed by double mass spectrometry

Minirhyzotrone - A nondestructive in situ video camera device inserted into a transparent tube buried in the rhizosphere to directly and repeatedly observe and photograph roots and their surroundings

Orobanche spp. - Botanical family in the Orobancheae characterized by unbranched above-ground stems and the absence of bracteoles Parasitic plant - A plant living on a host plant connected by a haustorium through which it withdraws water and assimilates

Phelipanche spp. - Botanical family in the Orobancheae characterized by branched above-ground stems and the presence of bracteoles PICKIT - An Israeli DSS developed for broomrape control in processing tomatoes based on a thermal time parasitism dynamics model and selective herbicide applications

POST - Treatment applied post emergence of weeds or crops

PPI - Treatment applied preplanting of crops followed by incorporation of the herbicide into the soil

PRE - Treatment applied pre-emergence of weeds or crops

Strigolactones - Plant hormones that induce seed germination in parasitic plants; the compounds contain three annelated rings connected by an enol ether unit with an $\alpha$-butenolide ring

Sulfonylurea herbicides - A subgroup of the ALS-inhibiting herbicides composed of a urea molecule and a sulfonylurea moiety 
broomrape in red clover; and sulfosulfuron and rimsulfuron to control Egyptian broomrape in tomato and potato.

\section{Sulfonylurea Herbicides for Controlling Egyptian Broomrape in Processing Tomato Crops}

In the mid-1990s, initial experiments to examine the efficacy of sulfonylurea herbicides in the control of Egyptian broomrape were performed under laboratory conditions using a system comprising polyethylene bags. It was found that the herbicides triasulfuron, chlorsulfuron, and rimsulfuron applied at the initial stages of parasitism, i.e., the preconditioning and germination stages, inhibited parasite development. Additionally, all herbicides controlled Egyptian broomrape tubercles post attachment to the tomato host roots. However, chlorsulfuron and triasulfuron were toxic to the tomato plants at $2.5 \mathrm{~g}$ a.i. $\mathrm{ha}^{-1}$ and $15 \mathrm{~g}$ a.i. ha ${ }^{-1}$, respectively. It was therefore

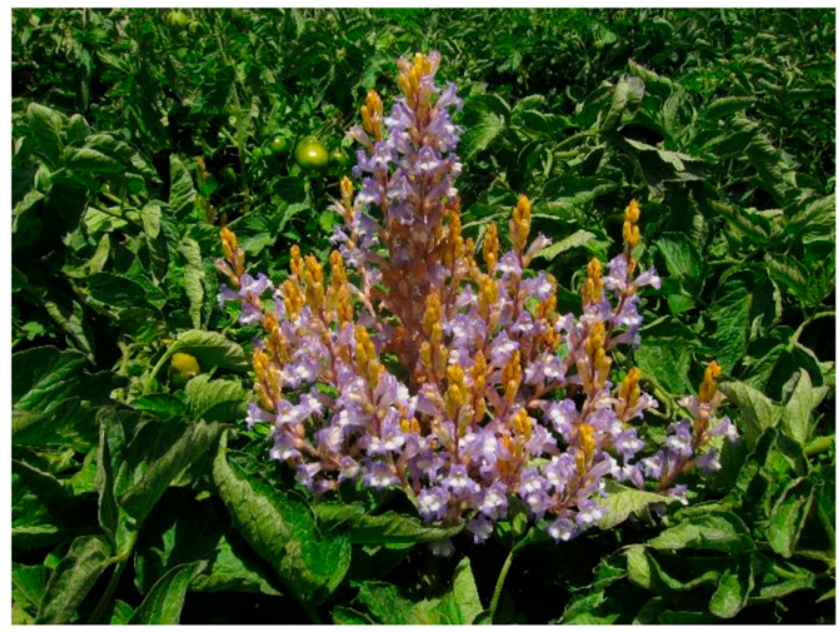

Fig. 2. A single Egyptian broomrape plant parasitizing a tomato plant. concluded that these two herbicides should be applied directly to the rhizosphere at lower rates than those previously recommended for these herbicides (Hershenhorn et al. 1998). Effective Egyptian broomrape control and high selectivity to tomato plants was indeed achieved under field conditions by delivering low doses of chlorsulfuron and triasulfuron via sprinkler irrigation (herbigation) at 2, 4, and 6 weeks after planting.

At the end of the 1990s, the herbicide sulfosulfuron was first introduced for weed control, at that stage in wheat. It was subsequently found that under greenhouse conditions, tomato plants were highly tolerant to the herbicide and its potential for broomrape control was high. The greenhouse experiments also showed that to improve the control efficacy, the herbicide should be incorporated into the soil so as to exert its activity in the rhizosphere (Eizenberg et al. 2004b). These findings led us to perform a series of field studies to compare different methodologies of incorporating the herbicide into the soil, i.e., by using a rototiller or via overhead irrigation (Eizenberg et al. 2012a).

The results of one of the first field studies performed in 2001 showed that preplanting incorporation (PPI) of the herbicides into the soil or foliar herbicide applications of sulfosulfuron and rimsulfuron (followed by $300 \mathrm{~m}^{3}$ of overhead irrigation) significantly reduced the infection rate of Egyptian broomrape in tomato. The data from this experiment demonstrated that sulfosulfuron, even at the lower rate of application ( 37.5 versus $75 \mathrm{~g} \mathrm{ha}^{-1}$ ), was more effective in broomrape control than rimsulfuron, which exhibited only moderate control efficacy. No damage from rimsulfuron or sulfosulfuron was observed to the treated tomatoes, and there was no reduction in yield compared with a $30 \%$ yield loss in the nontreated control (Fig. 4).

Although effective broomrape control was achieved in these experiments, late broomrape emergence was observed, namely, about five inflorescences per $\mathrm{m}^{2}$ of field when sulfosulfuron was applied and about 12 inflorescences per $\mathrm{m}^{2}$ when rimsulfuron was applied. These broomrape shoots did not cause damage to the tomato plants or reduce the tomato yields, but it should be stressed that even such

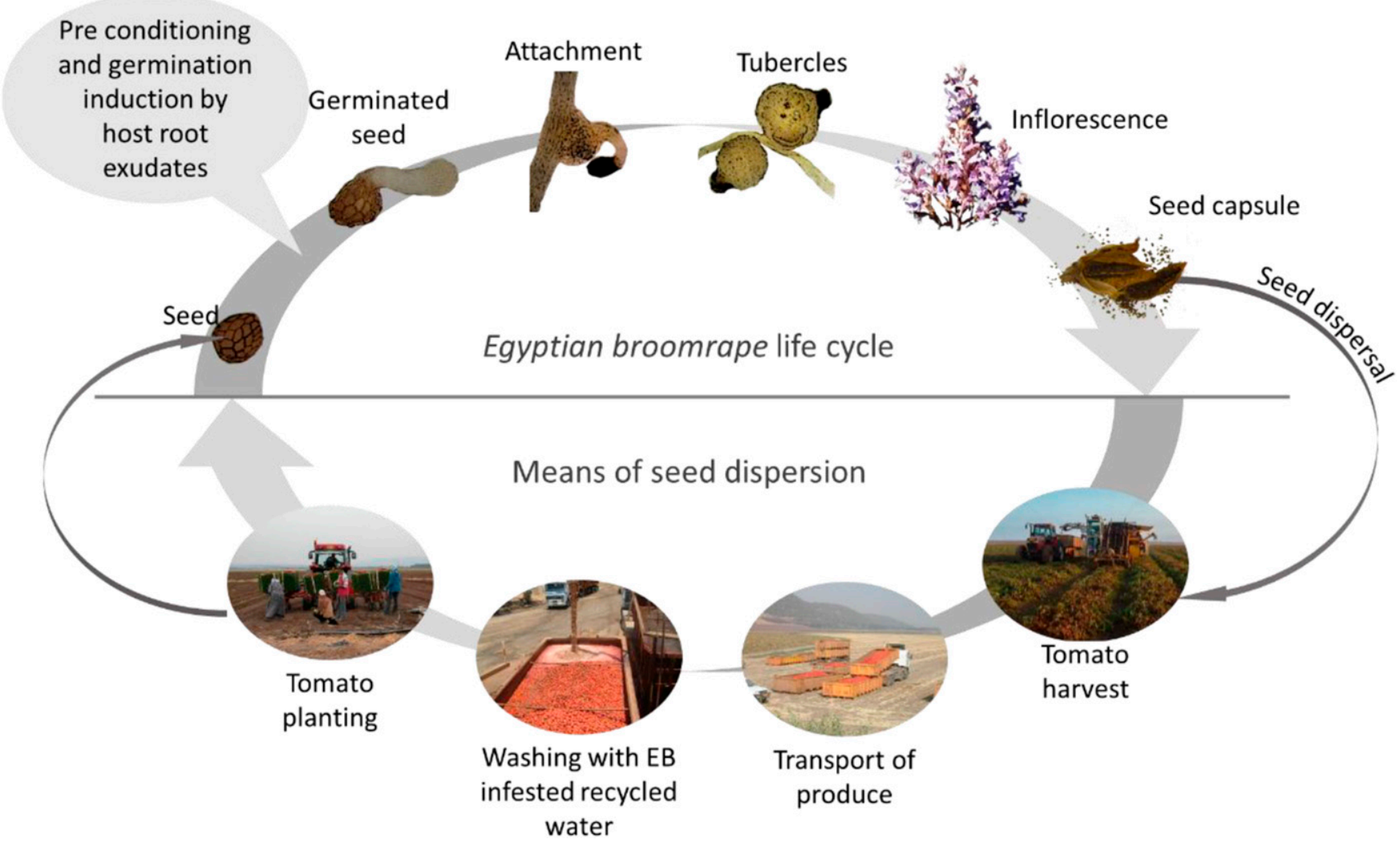

Fig. 3. Life cycle of Egyptian broomrape (EB) and agricultural practices leading to seed bank augmentation. 
'nondamaging' inflorescences must be destroyed to reduce future augmentation of the broomrape seed bank.

The first attempts to control Egyptian broomrape in processing tomato fields with the imidazolinone herbicide imazapic were also undertaken in the mid-1990s. The efficacy of this herbicide, applied by foliar spraying, was tested in laboratory, greenhouse, and field experiments. Studies conducted with the laboratory polyethylene bag system showed that the herbicide kills Egyptian broomrape only after attachment of the parasite to the host root, suggesting that the herbicide is delivered to the parasite through the host plant roots (Fig. 5).
The efficacy of spraying imazapic on tomato foliage before broomrape emergence was also tested, but it was found to cause damage to the tomato plants. Herbicide application led to flower abortion, reduced fruit setting, fruit deformation, and extensive vegetative growth, all resulting in severe impairment of both tomato quality and yields (Fig. 6). To overcome the injury caused by imazapic foliar application, two practices were proposed and tested: 1) foliar application of imazapic not earlier than 45 days before harvest, 45 days being the time between fruit setting and ripening, and 2) application of the herbicide directly to the rhizosphere via drip irrigation,

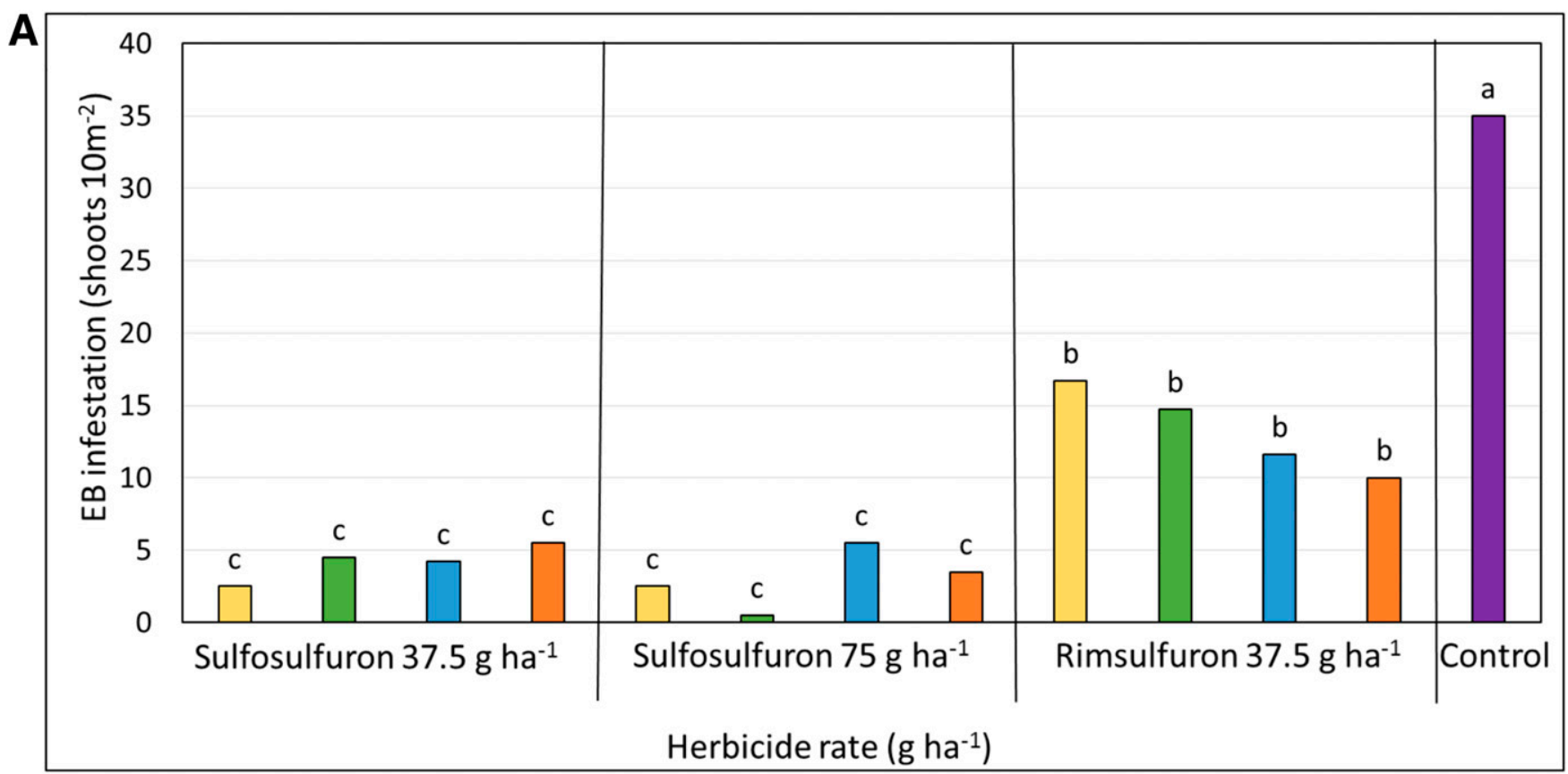

B

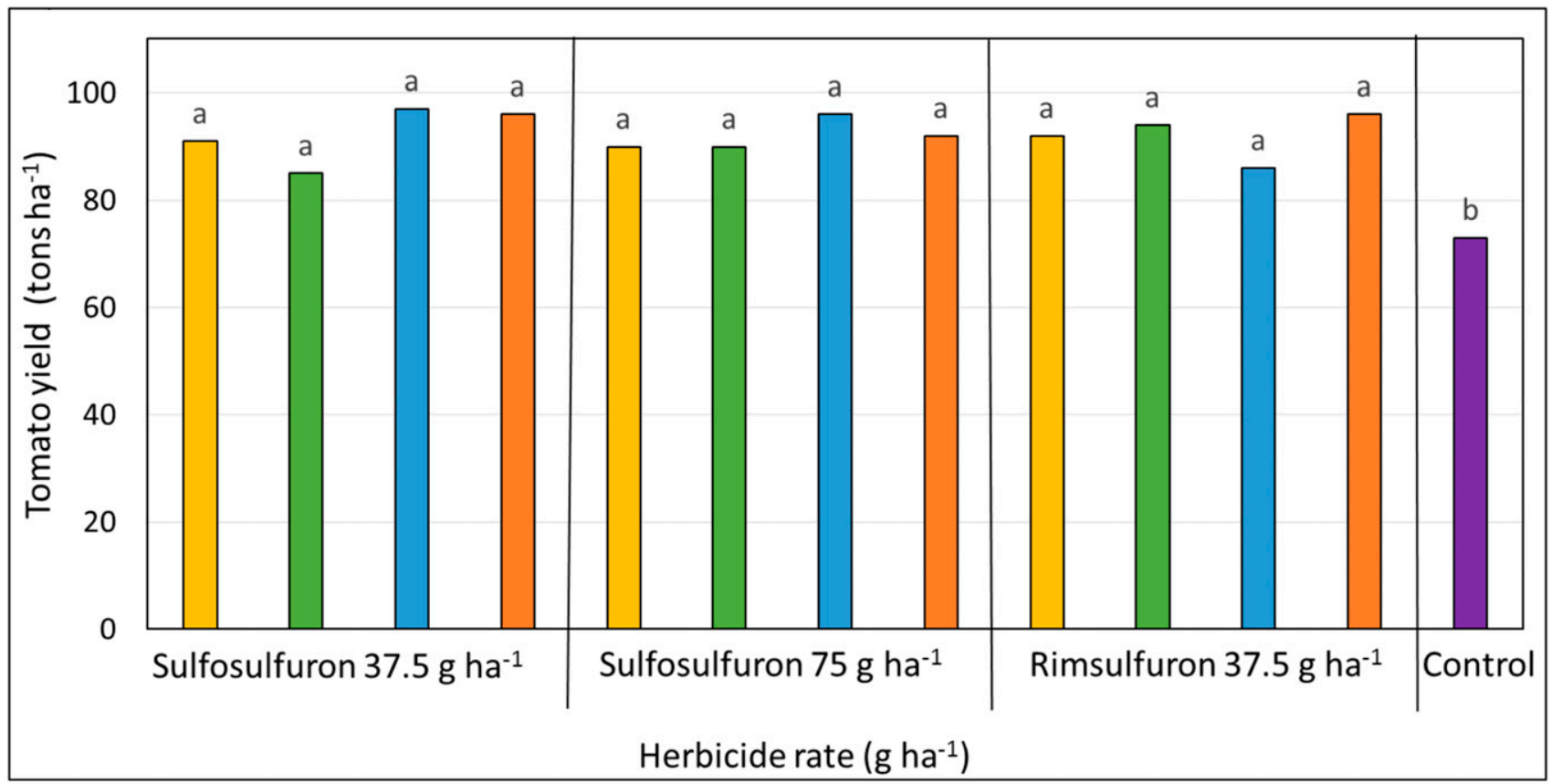

$\begin{array}{lccc}\text { POST (14, 28, } & \text { POST (14, } & \text { PPI+POST (-7, 28, } & \text { PPI+POST }(-7,28 \\ \text { 42 DAP }) & \text { 28 DAP }) & \text { 42 DAP }) & \text { DAP })\end{array}$

Fig. 4. Effect of preplanting incorporation (PPI) or post emergence application (POST) of rimsulfuron and sulfosulfuron on Egyptian broomrape control (A) and tomato yield (B) in the field experiment performed in 2001. PPI treatments were applied 7 days before planting. Bars labeled with different letters are not significantly different; Tukey-Kramer HSD, $P=0.05$. 
increasing crop safety and enabling application starting at 30 days after planting.

\section{Thermal Time Models for Predicting Parasitism Dynamics and Optimizing Chemical Control of Root Parasitic Weeds}

Tempo-spatial distribution of autotrophic plants (e.g., nonparasitic weeds) has been thoroughly studied (Kalivas et al. 2012), and many methodologies are available for their post emergence detection by remote sensing or visual scouting. However, this is not the case for root parasitic plants in which the major part of the life cycle takes place in the soil subsurface, making it impossible to visually detect and monitor weed development (Fig. 3). It was therefore realized that to facilitate control the parasite at its most susceptible phenological stage(s), it would be necessary to establish protocols for the application of ALS-inhibiting herbicides that would be based on a knowledge of parasitism dynamics and of specific Egyptian broomrape phenological developmental stages in the soil subsurface.

It is now generally accepted that a temporal modeling approach can be used to predict the parasitism dynamics under various climatic conditions and thereby to assist in optimizing herbicide application, i.e., by applying the herbicide at the most susceptible stage of parasite development (Eizenberg et al. 2006). Such a modeling approach aims to describe and facilitate predictions of host-parasitic weed interactions, phenological events, and parasitism dynamics. In particular, the models predict key stages in the parasite life cycle, such as seed germination, attachment to the host, tubercle development, and shoot emergence (Fig. 3). The introduction of the minirhizotron video camera and its adaptation for in-situ monitoring of broomrape development in the soil has indeed enabled us to define and predict the timing of the most sensitive stages of parasite development (Eizenberg et al. 2005b). This new technology has considerably increased the efficacy of chemical control of broomrape (Fig. 7).

Thermal time-based models are used for estimating specific phenological and development rates of weeds (Grundy 2003). In the case of parasitism dynamics of parasitic plants infecting crops, the commonly used parameter is accumulated growing degree days (GDD), which is computed as a function of cumulative daily temperatures, as follows: GDD $=\sum\left\{\left[\left(\mathrm{T}_{\max }+\mathrm{T}_{\min }\right) / 2\right]-\mathrm{T}_{\text {base }}\right\}$, where $\mathrm{T}_{\max }$ is the maximal daily temperature, $\mathrm{T}_{\min }$ is the minimal daily temperature,

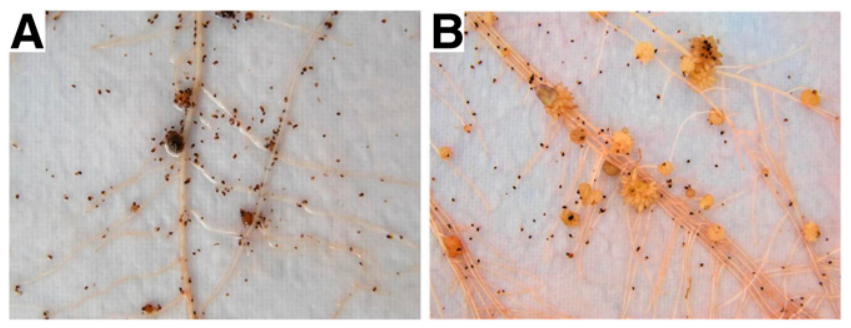

Fig. 5. Effect of imazapic application on Egyptian broomrape attached to tomato roots in the polyethylene bag system. (A) Treated with $5 \mathrm{ppb}$ imazapic. (B) Untreated control.

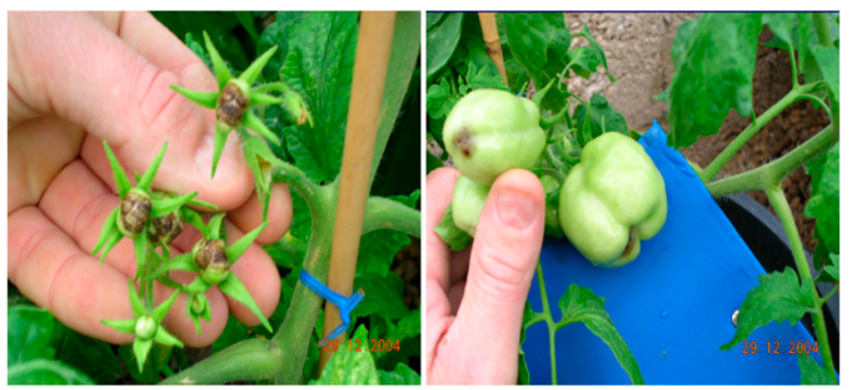

Fig. 6. Damage to tomato fruit caused by foliar application of $4.8 \mathrm{~g}$ a.i. ha ${ }^{-1}$ imazapic. Left, damage to fruit set. Right, damage to young fruits. and $\mathrm{T}_{\text {base }}$ is the minimal temperature for crop development. In the case of tomato, $\mathrm{T}_{\text {base }}=10^{\circ} \mathrm{C}$.

Thermal time models have been developed for several broomrape species and hosts, namely: small broomrape in red clover, sunflower broomrape in sunflower, Egyptian broomrape in tomato, potato, and carrot, and crenate broomrape in faba bean, green pea, and lentil (Cochavi et al. 2016; Eizenberg et al. 2004a, 2005a, 2012b; Ephrath et al. 2012; Hosseini et al. 2017; Pérez-de-Luque et al. 2016).

In the current feature article, we focus on the parasitism dynamics of Egyptian broomrape in processing tomatoes. A three-parameter nonlinear logistic equation characterized by lag, log, and maximal phases describes the parasitism dynamics (Ephrath et al. 2012):

$$
Y=\frac{a}{1+\left(\frac{G D D}{x_{0}}\right)^{b}}
$$

where $Y=$ broomrape number, $a=$ the upper asymptote (maximum), $x_{0}=$ inflection point (the GDD when $\mathrm{y}$ is $50 \%$ of maximal attachments), and $\mathrm{b}=$ the slope at $x_{0}$.

The parameters of the logistic equation enable estimation of specific events during the life cycle of Egyptian broomrape on tomato, including timing of the first attachments, tubercle development and accumulation, and timing of shoot emergence.

A series of experiments conducted under controlled temperature conditions in the phytotron, and validated in the field using a minirhizotron, estimated that the time from seed preconditioning and germination to the first attachments of Egyptian broomrape to tomato occurs after 200 GDD. The temporal distribution model assists in the optimization of herbicide application according to the target of herbicide action: germinating seeds, pre attachment stage, and post attachment to the tomato roots.

\section{Decision Support System (DSS) PICKIT for the Rational Management of Egyptian Broomrape in Tomato}

The thermal time modeling approach was applied for developing a DSS, designated PICKIT, for the smart management of Egyptian broomrape in tomato (Eizenberg et al. 2012a; Fig. 8). This DSS has four main components: (i) evaluation of broomrape infestation severity based on field history and eco-informatics, GIS, and infestation mapping (Cohen et al. 2017); (ii) computed thermal time (GDD) starting at tomato planting (Eizenberg et al. 2012a; Ephrath et al. 2012); (iii) prophylactic soil-applied chemical treatments by PPI of sulfosulfuron or foliar application of sulfosulfuron followed by overhead irrigation; and (iv) broomrape post-attachment treatments with drip chemigation or foliar application of imazapic.

The knowledge collected from the field experiments described above led to the development of the PICKIT DSS for rational

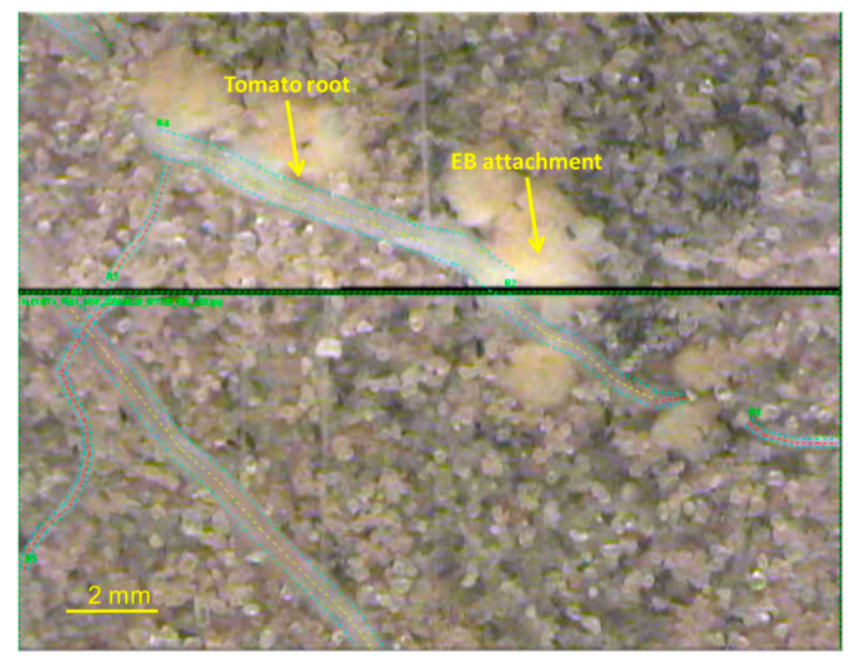

Fig. 7. Nondestructive in situ monitoring of tomato roots parasitized by Egyptian broomrape using a minirhizotron video camera. 
management of Egyptian broomrape in processing tomato (Fig. 8). Four application pathways were developed according to the Egyptian broomrape infestation severity and available application equipment: red, green, blue, and purple, as follows:

(a) Red pathway: For the most severe predicted infestation level of more than five Egyptian broomrape shoots $\mathrm{m}^{-2}$, $37.5 \mathrm{~g}$ a.i. $\mathrm{ha}^{-1}$ sulfosulfuron is applied three times post emergence (POST) at 200, 400, and 600 GDD, followed by $300 \mathrm{~m}^{2}$ of overhead irrigation. In addition, two doses of 4.8 a.i. $\mathrm{ha}^{-1}$ imazapic are applied at a later growth stage (less than 45 days before harvest). Overhead irrigation using linear, pivot, or sprinkler irrigation for incorporating the sulfosulfuron into the soil, is essential for the success of sulfosulfuron treatment.

(b) Green pathway: For medium predicted infestation levels of three to five Egyptian broomrape shoots $\mathrm{m}^{-2}$, a second option is possible: a single $37.5 \mathrm{~g}$ a.i. $\mathrm{ha}^{-1}$ PPI sulfosulfuron application 7 to 30 days before planting, followed by five 2.4 a.i. ha ${ }^{-1}$ imazapic drip herbigation applications at 400, 500, 600, 700, and 800 GDD, which are, in turn, followed by two additional 4.8 a.i. $\mathrm{ha}^{-1}$ imazapic applications at a later growth stage (less than 45 days before harvest).

(c) Blue pathway: For medium predicted infestation levels of three to five Egyptian broomrape shoots $\mathrm{m}^{-2}$, the treatment comprises a single $37.5 \mathrm{~g}$ a.i. $\mathrm{ha}^{-1}$ PPI sulfosulfuron application 0 to 60 days before planting, followed by two 4.8 a.i. ha ${ }^{-1}$ imazapic drip herbigation applications at 400 and 600 GDD, which are, in turn, followed by two 4.8 a.i. ha $^{-1}$ imazapic applications at a later growth stage (less than 45 days before harvest).

(d) Purple pathway: For very low (zero to two Egyptian broomrape shoots $\mathrm{m}^{-2}$ ) predicted or unknown infestation levels, the herbicide application protocol is based on the response to visual identification of Egyptian broomrape inflorescence emergence: only after Egyptian broomrape shoot emergence is a foliar application of 2.4 a.i. ha $^{-1}$ imazapic administered (less than 45 days before harvest). A second imazapic treatment, also of 2.4 a.i. $\mathrm{ha}^{-1}$, is applied 21 days later.

PICKIT was validated under field conditions using a minirhizotron camera for precise documenting of the parasite underground development and control (Eizenberg et al. 2012a). It was found that all the pathways significantly reduced Egyptian broomrape parasitism and increased tomato yield. Imazapic effectively controlled Egyptian broomrape at the stage of attachment or preshoot emergence when applied to tomato foliage without overhead irrigation. Furthermore, application of imazapic before parasite seed ripening killed the Egyptian broomrape seeds. Imazapic treatment at a stage earlier than 45 days before tomato harvest is toxic to the productive stages of the tomato, resulting in bud, flower, and fruit abortion (Fig. 6). Therefore, foliar imazapic should be applied only from 45 days before harvesting and onward to avoid damage to commercial tomato fields. Late foliar application of imazapic can also be effective for broomrape control at low Egyptian broomrape infestation levels where prophylactic sulfosulfuron treatments have not been given.

Infestation should be determined according to the categories that were proposed by Cohen et al. (2017), e.g., field history or neighboring
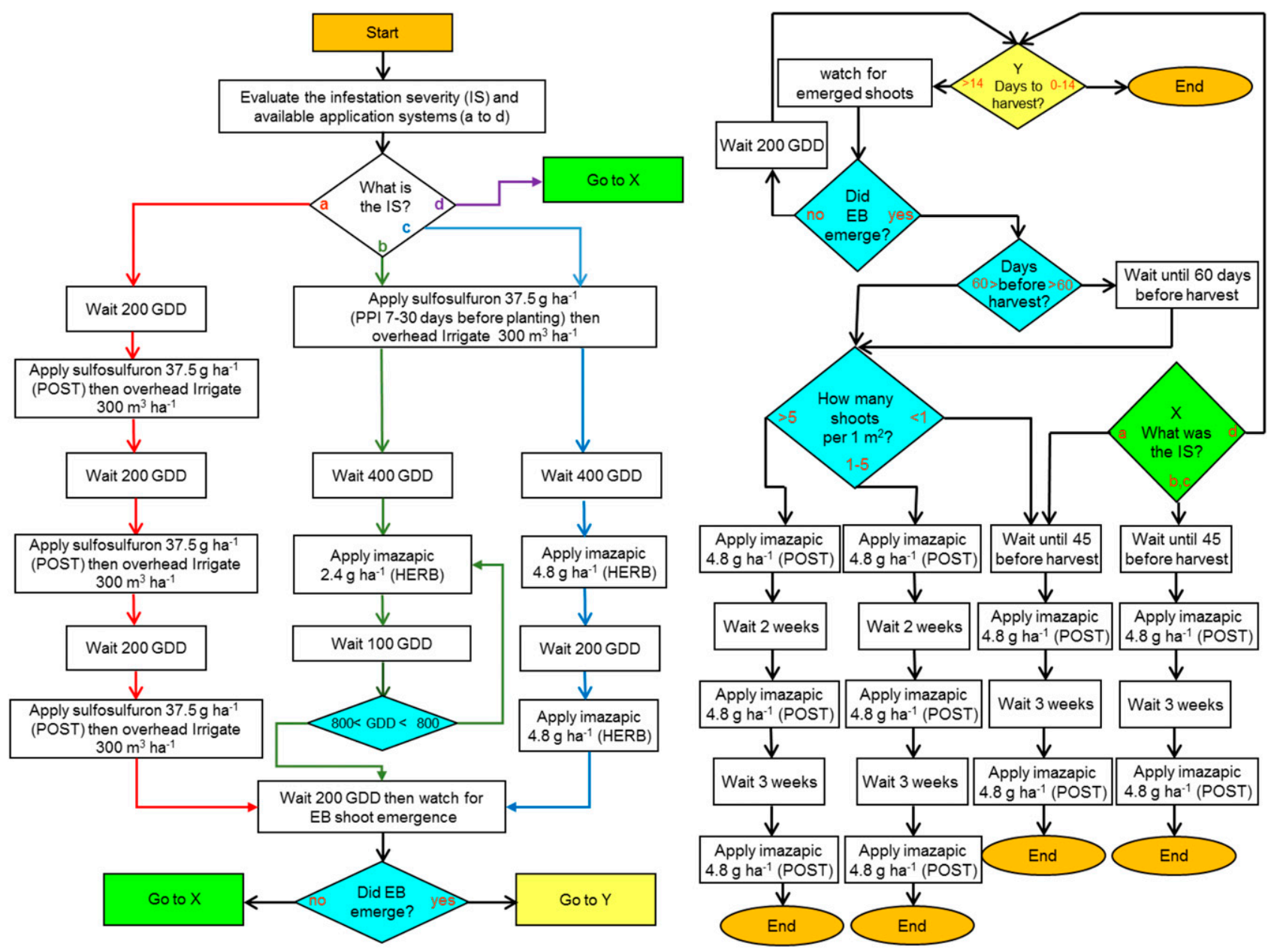

Fig. 8. The DSS PICKIT according to four Egyptian broomrape infestation severity pathways. See text for details. 
plots. If tomato was grown once or twice during the last 10 years, the severity for high infestation levels is high and the farmer will select the red pathway, which is considered as the most aggressive one. However, in the case of lacking information, the farmer can select the purple pathway. Another consideration that may affect the decision is equipment availability. The red pathway requires upper irrigation, e.g., moving pivot or sprinklers that are not always available to the farmer.

One of the main disadvantages of the PICKIT red pathway for rational broomrape management is the dependence on overhead irrigation to incorporate sulfosulfuron into the soil. This disadvantage has led to a preference for the green and blue pathways in which the common agricultural practice of drip irrigation is used. The prophylactic treatments with $37.5 \mathrm{~g}$ a.i. $\mathrm{ha}^{-1}$ sulfosulfuron were replaced with a PPI treatment, in which the herbicide is mechanically incorporated into the soil before tomato planting (Fig. 9). Furthermore, the introduction of a low-flow drip irrigation technology $(1.0$ liter/h volume, 20 to $50 \mathrm{~cm}$ distance between drippers) facilitates uniform distribution of water that, in turn, allows uniform application of chemicals via herbigation. Delivery of herbicides through the drip irrigation system in field experiments is achieved by the use of an electrical pump that is connected to the head of the drip irrigation system (Fig. 10). Empirical studies showed that, for optimal herbigation results, the herbicide must be applied in the last third of each irrigation cycle. Our studies showed that late imazapic foliar applications or drip herbigation controlled Egyptian broomrape attachments (Fig. 5) and escaped Egyptian broomrape shoots (Fig. 11), thereby preventing parasite seedbank enrichment (Eizenberg et al. 2012a).

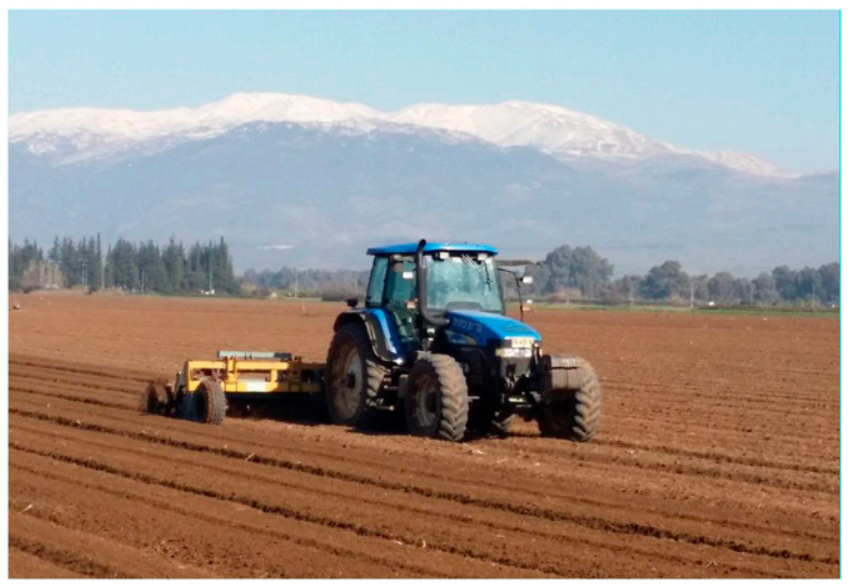

Fig. 9. Preplanting incorporation (PPI) of sulfosulfuron with a rotovator in December 2014, 2 months before tomato planting in a field trial in the Upper Galilee in 2015.

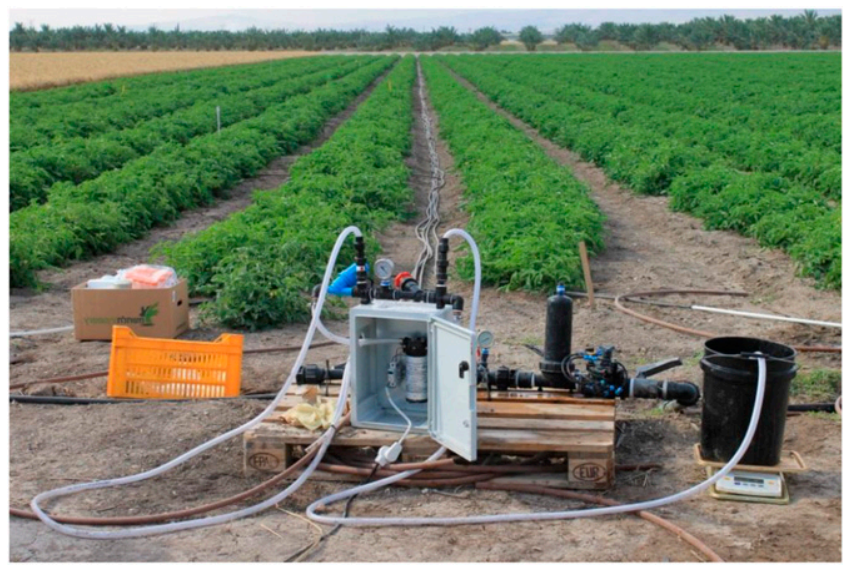

Fig. 10. Electric pump setup for injection of herbicides into drip line systems in field experiments.
For trials conducted in experimental field plots we used the special electric pump, but once the technique is implemented in big commercial plots, the farmers use their existing liquid fertilizer injecting systems or their sprayers connected to the drip irrigation system main lines to deliver the herbicides.

To better understand and improve the DSS for control of Egyptian broomrape in tomato, precise analysis of imazapic concentrations at different stages is required, namely, at the point of injection, throughout the irrigation system, in the soil, and finally in the parasite and tomato plants. For this purpose, an imazapic extraction scheme from water, soil, and plants and an LC/MSMS imazapic determination protocol were developed that allowed detection of herbicide concentrations as low as $1 \mathrm{ppb}$. The relevant studies included laboratory, greenhouse, and field experiments in which imazapic concentrations were determined in the drip irrigation system (Fig. 12, left), at different soil depths, at different distances from the dripline (Fig. 12, right), and in the tomato plant. The chemical analysis was supplemented by parallel broomrape shoot counts, tomato plant evaluations, and tomato yield determinations.

The above studies revealed that the broomrape-lethal imazapic concentration that is selective to the tomato plants lies in the range of 2 to $4 \mathrm{ppb}$. We found that the $\mathrm{t}_{1 / 2}$ of imazapic under irrigated field conditions is short, namely 7 days, and that the herbicide concentration near the dripper decreases rapidly, such that 7 days after application there is no herbicide at a soil depth of 20 to $30 \mathrm{~cm}$ (Table 1). To address the problem of rapid imazapic breakdown, we tested a more frequent application regime of 100 GDD rather than 200 GDD, which corresponded under our conditions to roughly weekly applications versus applications every 2 weeks. The more frequent application regime reduced broomrape parasitism throughout the growing period (Table 2, Fig. 13), enabling the maintenance of

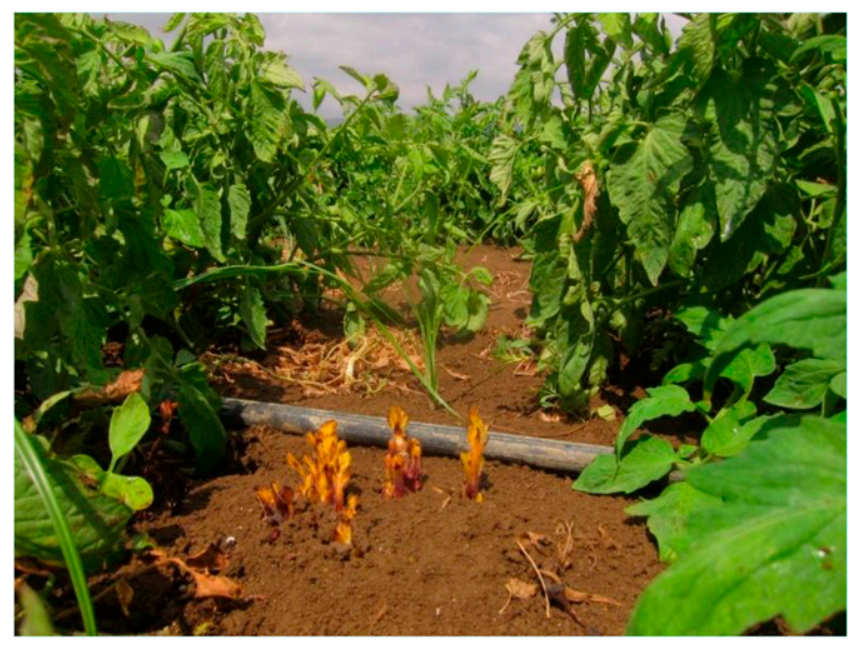

Fig. 11. Typical damage to late emerging Egyptian broomrape shoots by imazapic herbigation.

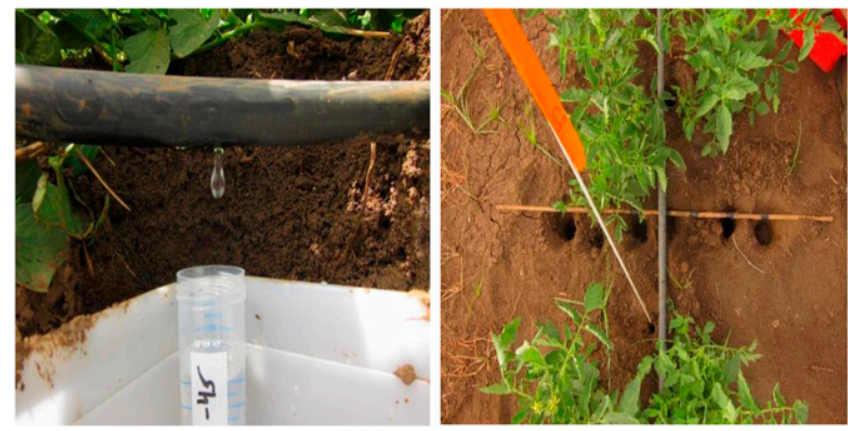

Fig. 12. Sampling of water and soil in field trials for imazapic determination by LCMSMS: (Left) Water sampling of the drip irrigation system. (Right) Soil sampling at vertical distances from the dripper. 
broomrape lethality together with higher selectivity to the tomato crop (Figs. 12 and 13), and hence resulting in increased tomato yields. The regression analysis given in Table 3 shows significant differences between the dynamics of Egyptian broomrape development in the different treatments. Higher control efficacy (lower $\mathrm{ED}_{50}$ ) was obtained for the green pathway (green line), followed by the blue pathway (blue line), compared with the nontreated control (magenta line) (Fig. 13).

The four pathways of the DSS PICKIT were validated under commercial field conditions in experimental plots $\left(20\right.$ to $\left.40 \mathrm{~m}^{2}\right)$ in northern Israel between 2010 and 2015. All options reduced Egyptian broomrape parasitism and increased tomato yields compared with the

Table 1. Field trial held at the Eden Research Station in 2014 with weekly treatments of imazapic via the drip irrigation system. The first application of imazapic was given at $4.8 \mathrm{~g}$ a.i. $\mathrm{ha}^{-1}$, followed by eight weekly applications of $2.4 \mathrm{~g}$ a.i. $\mathrm{ha}^{-1}$. The table shows the imazapic concentration in the soil at a 0 - to 30 -cm soil depth at different distances from the dripper, 1 and 7 days after the first application (before the second application).

\begin{tabular}{lcc}
\hline & \multicolumn{2}{c}{$\begin{array}{c}\text { Concentration of imazapic } \\
\text { in the soil }(\mathbf{p p b})\end{array}$} \\
\cline { 2 - 3 } $\begin{array}{l}\text { Distance from the } \\
\text { dripper }(\mathbf{c m})\end{array}$ & $\begin{array}{c}\mathbf{1} \text { day after } \\
\text { treatment }\end{array}$ & $\begin{array}{c}\mathbf{7} \text { days after } \\
\text { treatment }\end{array}$ \\
\hline 0 & 1.222 & 0 \\
10 & 1.880 & 0 \\
20 & 2.653 & 0.508 \\
30 & 2.421 & 2.132 \\
\hline
\end{tabular}

Table 2. Final imazapic concentrations in the soil before the tomato harvest in the 2014 Eden field trial at a soil depth of 0 to $30 \mathrm{~cm}$ at different distances from the drippers in weekly versus fortnightly herbigation regimes. Total herbicide applied in both regimes was $15.4 \mathrm{~g}$ a.i. $\mathrm{ha}^{-1}$.

\begin{tabular}{lcc}
\hline & \multicolumn{2}{c}{$\begin{array}{c}\text { Concentration of imazapic in the soil } \\
(\mathbf{p p b})\end{array}$} \\
\cline { 2 - 3 } $\begin{array}{l}\text { Distance from the } \\
\text { dripper }(\mathbf{c m})\end{array}$ & Weekly regime & Fortnightly regime \\
\hline 0 & 1.020 & 0.392 \\
10 & 1.103 & 0.320 \\
20 & 2.200 & 0.694 \\
30 & 1.504 & 0.673 \\
\hline
\end{tabular}

nontreated controls (Fig. 14). For example, in 2014, in Ein Harod Ichud in northern Israel, an average of 1,200 Egyptian broomrape shoots were counted in $20 \mathrm{~m}^{2}$ in the nontreated control plots compared with complete control when PICKIT was used. An impressive average tomato yield increase of $40 \mathrm{tha}^{-1}$ was achieved in these plots compared with the nontreated control plots, leading to substantial increase of US $\$ 4,731 \mathrm{ha}^{-1}$ net revenue for the farmer (Table 4). In 2016, PICKIT was implemented for seven tomato varieties in 33 commercial Egyptian broomrape infested fields, resulting in 95\% broomrape control and yielding an average of $122 \mathrm{t} \mathrm{ha}^{-1}$ tomatoes (Fig. 15).

\section{Concluding Remarks and Future Approaches}

In this review, we summarize 20 years of theoretical and applied research aimed at solving the specific problem of broomrape control in the production of processing tomatoes. The research was conducted in laboratories, greenhouses, experimental plots, and semi-commercial fields (Fig. 16), and was finally implemented in commercial fields in Israel.

The uniqueness of this research lies in the dynamics and interaction between research teams, extension personnel, commercial enterprises (canning, agrochemical, and irrigation companies), farmers and farmer organizations, and in the methodical procedure of taking the research from laboratory experiments to commercial field operations. The best indication of success of this research lies in the adaptation of the recommended broomrape management schemes by farmers in Israel.

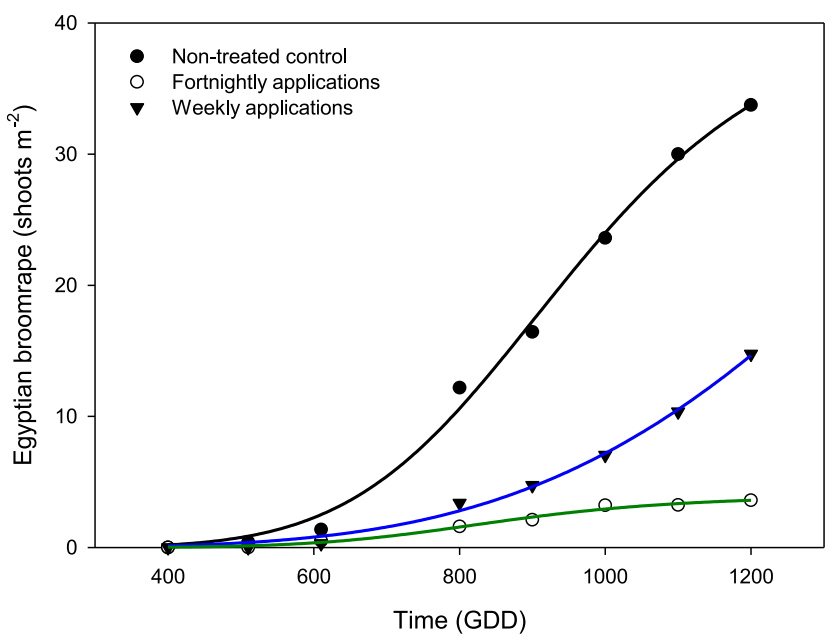

Fig. 13. Egyptian broomrape infestation in the weekly and fortnightly imazapic treatments during the course of the 2014 Eden field trial.

Table 3. Parameters estimated for the log-log equation for the dynamics of emergence of Egyptian broomrape inflorescences following imazapic herbigation

\begin{tabular}{|c|c|c|c|c|c|}
\hline Control & Coefficient & SE (a) & $P(\mathbf{a})$ & RMSE & $P$ (regression) \\
\hline $\begin{array}{l}\mathrm{a}^{\mathrm{a}} \\
\mathrm{b}^{\mathrm{b}} \\
\mathrm{X}_{0}{ }^{\mathrm{c}}\end{array}$ & $\begin{array}{r}37.99 \\
-6.82 \\
919.72\end{array}$ & $\begin{array}{r}2.15 \\
0.85 \\
21.42\end{array}$ & $\begin{array}{c}<0.0001 \\
0.001 \\
<0.0001\end{array}$ & 1.13 & $<0.0001$ \\
\hline $\begin{array}{l}\text { Weekly applications } \\
\text { A } \\
\text { B } \\
\mathrm{X}_{0}\end{array}$ & $\begin{array}{c}\text { B } \\
20.1303 \\
-6.3882 \\
1,078.1077\end{array}$ & $\begin{array}{c}\text { SE (b) } \\
3.871 \\
1.376 \\
77.5481\end{array}$ & $\begin{array}{c}\boldsymbol{P}(\mathbf{b}) \\
0.002 \\
0.0035 \\
<0.0001\end{array}$ & $\begin{array}{c}\text { RMSE } \\
0.78\end{array}$ & $\begin{array}{c}\boldsymbol{P} \text { (regression) } \\
<0.0001\end{array}$ \\
\hline $\begin{array}{l}\text { Fortnightly applications } \\
\text { A } \\
\text { B } \\
\text { X }_{0}\end{array}$ & $\begin{array}{c}\mathbf{X}_{\mathbf{0}} \\
3.8633 \\
-6.8612 \\
845.8005\end{array}$ & $\begin{array}{r}\text { SE }\left(\mathbf{X}_{\mathbf{0}}\right) \\
0.2263 \\
1.1489 \\
23.0404\end{array}$ & $\begin{array}{c}\boldsymbol{P}\left(\mathbf{X}_{\mathbf{0}}\right) \\
<0.0001 \\
0.001 \\
<0.000\end{array}$ & $\begin{array}{c}\text { RMSE } \\
0.17\end{array}$ & $\begin{array}{c}\boldsymbol{P} \text { (regression) } \\
<0.0001\end{array}$ \\
\hline
\end{tabular}

${ }^{\mathrm{a}}$ Maximal number of Egyptian broomrape emergence.

${ }^{\mathrm{b}}$ Time required for $50 \%$ of maximal inflorescence emergence (inflection point).

${ }^{\mathrm{c}}$ Slope at $\mathrm{X}_{0}$. 


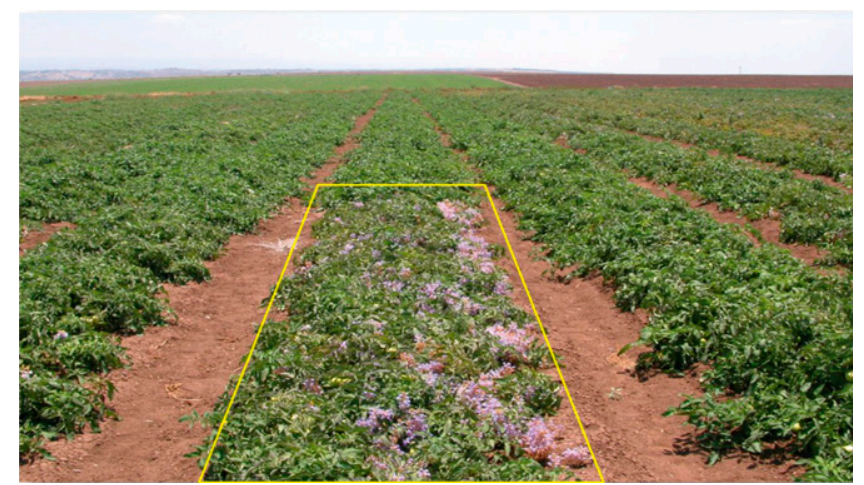

Fig. 14. Nontreated control plot in a PICKIT-managed commercial tomato field in northern Israel, 2011.

Table 4. PICKIT broomrape management balance sheet ${ }^{\mathrm{a}}$

\begin{tabular}{lc}
\hline Additional costs & Cost/income $(\mathbf{\$} / \mathbf{h a})^{\mathbf{b}}$ \\
\hline Rototilling & 112 \\
Sulfosulfuron $50 \mathrm{~g} \mathrm{ha}^{-1}$ & 108 \\
Sulfosulfuron application (sprayer) & 24 \\
Imazapic $80 \mathrm{~g} \mathrm{ha}^{-1}$ (split application) & 275 \\
Total cost & 519 \\
Additional income & $5,250^{\mathrm{c}}$ \\
Additional yield: $50 \mathrm{t} \mathrm{ha}^{-1}$ & 4,731 \\
Net revenue & \\
${ }^{\mathrm{a}}$ Summary of five semi-commercial plots treated in 2014, 1.5 to $2.5 \mathrm{ha}$ \\
each. \\
b Exchange rate of US $\$ 1=3.5 \mathrm{NIS}$. \\
${ }^{\mathrm{c}}$ Based on a tomato price of $\$ 105$ ton $^{-1}$.
\end{tabular}

The first step in delineating a successful control strategy lies in understanding the biology, morphology, and genomics of parasitic weeds - an understanding that has certainly deepened in the past two decades. New knowledge regarding host-parasite relationships and parasitism dynamics has enabled us to focus on specific phenological events and developmental stages at which the parasite is most vulnerable to control measures. In this article, we show that effective Egyptian broomrape management can be achieved by integrating tempo-spatial modeling, GIS (mapping and field history), and smart chemical application. For optimal application and herbicide delivery through irrigation systems, knowledge regarding water, solute, plant, soil, and herbicide properties must be applied, and the DSS aids farmers to include all these components into a practical management protocol. Broadening the use of chemical control of root parasitic weeds

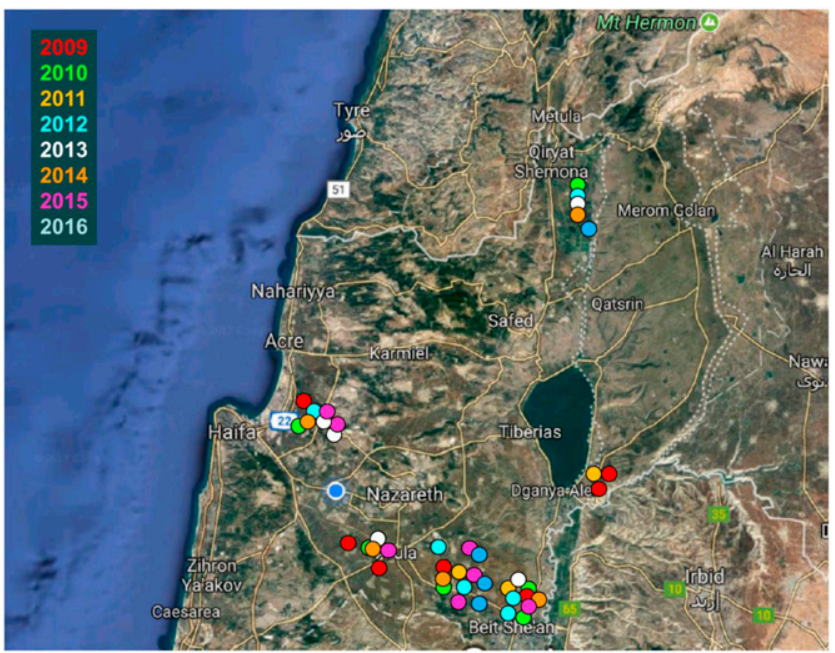

Fig. 16. Location of field experiments conducted in northern Israel over an 8-year period, 2009-2016.

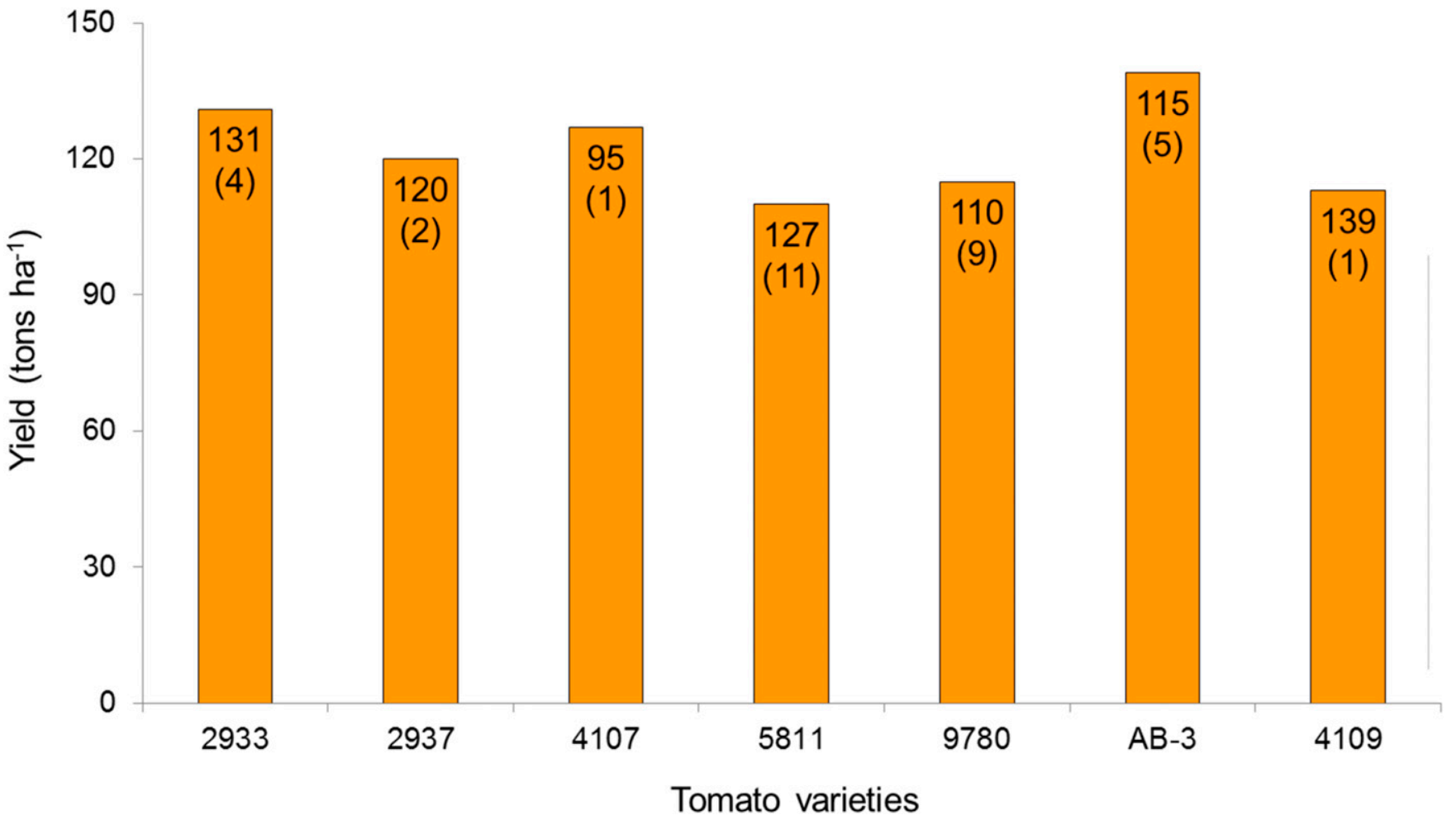

Fig. 15. Yields obtained in commercial processing tomato fields using the PICKIT Egyptian broomrape control program in the 2016 season. Data were obtained from 33 commercial fields. Total area for each variety is presented on the top of each bar, and the number of fields is given in parentheses. The average yield was 118 tons ha ${ }^{-1}$. 
to additional infested areas in different climatic and varied agricultural practices regions will require tailoring of the DSS to the new specific conditions.

To date, the most efficient chemical control means are the ALSinhibiting sulfonylurea and imidazolinone herbicides. Unfortunately, the history of these compounds, namely, the rapid development of herbicide resistance, indicates a high potential for the development of sulfonylurea-resistant broomrape. Thus, to reduce the risk of herbicide resistance, these herbicides should be used rationally in weed management strategies that include crop (non-hosts) and herbicide (different chemical groups) rotations.

Current thinking about the smart chemical management of both autotropic and parasitic weeds aims at adopting more sustainable technologies. In particular, for root parasitic weeds, the tempo-spatial distribution of the parasite must be estimated before proposing management tactics. This approach is based on estimating the heterogeneity within fields and regions, taking into consideration the historical background of the fields, and analyzing and defining the sources of the heterogeneity. Such an analysis will enable herbicide application solely at the precise infested locations in the field and thereby reduce the herbicide application rate. Site-specific weed management comprising a combination of field history data and GIS technology, namely, infestation identification and mapping, is thus the most promising means for increasing the precision of parasitic weed control.

New horizons will also be opened by the new technologies of lowflow drip irrigation systems and hyperspectral sensoring. Low-flow drip irrigation systems deliver water uniformly along the bed at low pressure, thereby enabling more precise chemigation methodologies. Hyperspectral sensors can be exploited for the detection of early Egyptian broomrape infection, as has been shown in research with sunflower broomrape parasitizing sunflower (Cochavi et al. 2017). Finally, the rapid introduction of networking and sharing technology by end users (farmers and virtual communities) also holds promise for improving broomrape control, since sharing frameworks enable facile transfer of data (such as herbicide resistance, meteorological data for modeling, DSS) between farmers, research intuitions, and extension services as well as between regions and countries.

We strongly believe that an integrated weed management approach is needed to ensure successful and sustainable parasitic plant control (Goldwasser and Rodenburg 2013). Extensive efforts should be devoted to breeding broomrape- and herbicide-resistant crops, and ideally to combining the two types of resistance to breed crossresistant crops. The sources of parasite tolerance and resistance in crops may be obtained by traditional mutagenesis and classical breeding strategies of foreign genetic material from wild-type germplasm together with recently developed gene editing techniques, such as CRISPR-Cas9 (Ran et al. 2013). The same strategy should be utilized to develop host crop herbicide-tolerant or herbicide-resistant varieties that will allow effective control of broomrape, such as the Clearfield varieties. There is no doubt that crop resistance to herbicides represents the next generation in chemical control of parasitic weeds. The newly revealed broomrape and Striga transcriptomes (Westwood et al. 2012) may assist in the improvement of herbicide use and control efficacy. In the past, the biological control approach was proposed as an optional nonchemical tool for broomrape management, but to date there are no commercial agents that are efficient and cost-effective under field conditions. Nevertheless, the search for new effective biological agents should continue. In recent years, extensive research has been devoted to parasitic plant germination factors, namely, to the role played by host strigolactones and sesquiterpene lactones in inducing specific broomrape seed germination. The exact genetics, chemistry, production sites (organs), and receptors, and the manipulation of these factors may play an important role in future broomrape management schemes.

Finally, parasitic plants, including broomrape, continue to pose a significant threat to food security in numerous communities around the globe, mainly in developing countries. In addition, climate change is promoting the spread of the parasitic plant threat to new food-producing regions. Increased basic and applied research based on new scientific and technology knowledge and the integration of this know-how with current knowledge should therefore be continued apace to deepen the understanding of parasitic plant-host plant interactions and control measures and thereby to ensure the food security of communities the world over.

\section{Acknowledgments}

Our sincere thanks for the invaluable assistance of our colleagues and the institutions that participated or supported this research: Shaul Graph, Guy Achdari Eitan Avivi, On Rabinowitz, Baruch Rubin, Gadi Tal, Mali Dagan, Yechezkel Shifroni, Dubi Raz, Yonatan Ephrath, Josheph Hershenhorn, Dina Plachine, Tal Shilo, Amit Paporish, Zeev Gerstle, Ahmed Nasser, Rafel Kriger, Hillel Manor Tal Lande, Yiftach Giladi, Joel Rubin, the Weed Department of the Agricultura Research Organization in Newe Ya'ar, the Weed Lab in the Faculty of Agriculture of the Hebrew University of Jerusalem, Upper Galilee and Eden research stations, the Tomato Growers Vegetable Board of Israel, the canning tomato industries, 'Adama,' and Luxemburg 'Hishtil' nurseries.

\section{Dedication}

This article is dedicated to the late Dr. Yeshayahu Kleifeld ("Shieke") (19342015) who was the head of the Newe Yaar Weed Research Department of the Agricultural Research Organization of Israel (1981-1999). Shieke initiated much of the basic and applied research on broomrape, including the control of the parasite through drip irrigation systems, on which he worked until his last day. The authors of this article were students of Shieke and the research and findings in this article are based on the broad foundations laid down by him.

\section{Literature Cited}

Castejon-Muñoz, M., Romero-Muñoz, F., and Garcia-Torres, L. 1993. Effect of planting date on broomrape (Orobanche cernua Loefl.) infections in sunflower (Helianthus annuus L.). Weed Res. 33:171-176.

Cochavi, A., Rapaport, T., Gendler, T., Karnieli, A., Eizenberg, H., Rachmilevitch S., and Ephrath, J. E. 2017. Recognition of Orobanche cumana below-ground parasitism through physiological and hyper spectral measurements in sunflower (Helianthus annuus L.). Front. Plant Sci. 8:909.

Cochavi, A., Rubin, B., Achdari, G., and Eizenberg, H. 2016. Thermal time model for Egyptian broomrape (Phelipanche aegyptiaca) parasitism dynamics in carrot (Daucus carota L.): field validation. Front. Plant Sci. 7:1807.

Cohen, Y., Roei, I., Blank, L., Goldshtein, E., and Eizenberg, H. 2017. Spatial spread of the root parasitic weed Phelipanche aegyptiaca in Processing tomatoes by using ecoinformatics and spatial analysis. Front. Plant Sci. 8:973.

Eizenberg, H., Aly, R., and Cohen, Y. 2012a. Technologies for smart chemical control of broomrape (Orobanche spp. and Phelipanche spp.). Weed Sci. 60:316-323.

Eizenberg, H., Colquhoun, J., and Mallory-Smith, C. 2005a. A predictive degreedays model for small broomrape (Orobanche minor) parasitism in red clover in Oregon. Weed Sci. 53:37-40.

Eizenberg, H., Colquhoun, J. B., and Mallory-Smith, C. A. 2004a. The relationship between temperature and small broomrape (Orobanche minor) parasitism in red clover (Trifolium pratense). Weed Sci. 52:735-741.

Eizenberg, H., Colquhoun, J. B., and Mallory-Smith, C. A. 2006. Imazamox application timing for small broomrape (Orobanche minor) control in red clover. Weed Sci. 54:923-927.

Eizenberg, H., Goldwasser, Y., Golan, S., Plakhine, D., and Hershenhorn, J. 2004b. Egyptian broomrape (Orobanche aegyptiaca) control in tomato with sulfonylurea herbicides greenhouse studies. Weed Technol. 18:490-496.

Eizenberg, H., Hershenhorn, J., Achdari, G., and Ephrath, J. E. 2012b. A thermal time model for predicting parasitism of Orobanche cumana in irrigated sunflower-Field validation. Field Crops Res. 137:49-55.

Eizenberg, H., Hershenhorn, J., Ephrath, J. E., and Kanampiu, F. 2013. Chemical control. Pages 415-432 in: Parasitic Orobanchaceae: Parasitic Mechanisms and Control Strategies. D. M. Joel, J. Gressel, and L. J. Musselman, eds. Springer Verlag, Berlin, Heidelberg.

Eizenberg, H., Shtienberg, D., Silberbush, M., and Ephrath, J. E. 2005b. A new method for in-situ monitoring of the underground development of Orobanche cumana in sunflower (Helianthus annuus) with a mini-rhizotron. Ann. Bot. 96:1137-1140.

Ephrath, J. E., and Eizenberg, H. 2010. Quantification the dynamics of Orobanche cumana and Phelibanche aegyptiaca parasitism in confectionery sunflower. Weed Res. 50:140-152.

Ephrath, J. E., Hershenhorn, J., Achdari, G., Bringer, S., and Eizenberg, H. 2012. Use of logistic equation for detection of the initial parasitism phase of Egyptian broomrape (Phelipanche aegyptiaca) in tomato. Weed Sci. 60:57-63.

Fernández-Aparicio, M., Reboud, X., and Gibot-Leclerc, S. 2016. Broomrape weeds. Underground mechanisms of parasitism and associated strategies for their control: a review. Front. Plant Sci. 7:135.

Fernández-Aparicio, M., Yoneyama, K., and Rubiales, D. 2011. The role of strigolactones in host specificity of Orobanche and Phelipanche seed germination. Seed Sci. Res. 21:55-61. 


\section{Hanan Eizenberg}

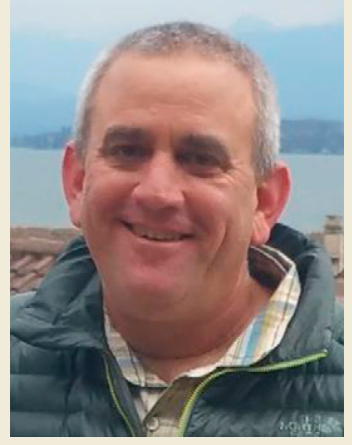

Professor Hanan Eizenberg is a research scientist and current chair of the Weed Research Section at the Newe Ya'ar Research Center, Institute of Plant Protection, A.R.O., The Volcani Center, Israel. He received his B.Sc., M.Sc., and Ph.D. degrees from the Faculty of Agricultural Food and Environmental Sciences of The Hebrew University of Jerusalem, Rehovot, Israel, and is currently a lecturer there and at the Tel Hai College, Israel. His research focuses on all aspects of weed science and control, including weed modeling, precision agriculture, invasive and troublesome weeds, and parasitic plants, the last of which were the subject of his M.Sc. and Ph.D. theses. He served as the president of the Weed Science Society of Israel in 2007-2009 and at present is the deputy director of the governing board of the Newe Ya'ar Research Center.

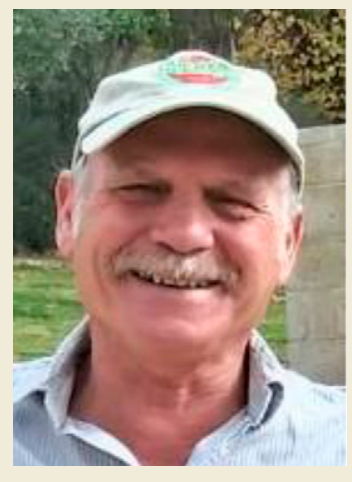

\section{Yaakov Goldwasser}

Dr. Yaakov Goldwasser is a research scientist at the Weed Research Section, Newe Ya'ar Research Center, Institute of Plant Protection, A.R.O., The Volcani Center, Israel, and a researcher at the R.H. Smith Institute of Plant Sciences and Genetics, Faculty of Agricultural, Food and Environmental Sciences, The Hebrew University of Jerusalem, Rehovot. He received his B.Sc., M.Sc., and Ph.D. degrees from the Hebrew University of Jerusalem, with research for the two graduate degrees centering on parasitic plants. In addition to continuing research on these plants, he also focuses on chemical and non-chemical weed control. He served as the president of the Weed Science Society of Israel in 2011-2013.

Finch-Savage, W., Steckel, J. R., and Phelps, K. 1998. Germination and postgermination growth to carrot seedling emergence: predictive threshold models and sources of variation between sowing occasions. New Phytol. 139:505-516.

Foy, C. L., Jain, R., and Jacobsohn, R. 1989. Recent approaches for chemical control of broomrape (Orobanche spp.). Rev. Weed Sci 4:123-152.

Goldwasser, Y., and Kleifeld, Y. 2004. Recent approaches to Orobanche management - a review. Pages 439-466 in: Weed Biology and Management. Inderjit ed., Kluwer Academic Publishers, Dordrecht, The Netherlands.

Goldwasser, Y., Kleifeld, Y., Golan, S., Barguiti, A., and Rubin, B. 1995. Dissipation of metham-sodium from soil and its effect on the control of Orobanche aegyptiaca. Weed Res. 35:445-452.

Goldwasser, Y., and Rodenburg, J. 2013. Integrated agronomic management of parasitic weed seed banks. Pages 393-413 in: Parasitic Orobanchaceae: Parasitic Mechanisms and Control Strategies. D. M. Joel, J. Gressel, and L. J. Musselman, eds. Springer Verlag, Berlin, Heidelberg.

Grundy, A. 2003. Predicting weed emergence: A review of approaches and future challenges. Weed Res. 43:1-11.

Heide-Jørgensen, H. S. 2013. Introduction: The parasitic syndrome in higher plants. Pages 1-18 in: Parasitic Orobanchaceae: Parasitic Mechanisms and Control Strategies. D. M. Joel, J. Gressel, and L. J. Musselman, eds. Springer Verlag, Berlin, Heidelberg.

Hershenhorn, J., Eizenberg, H., Dor, E., Kapulnik, Y., and Goldwasser, Y. 2009. Phelipanche aegyptiaca management in tomato. Weed Res. 49:34-47.

Hershenhorn, J., Goldwasser, Y., Plakhine, D., Aly, R., Blumenfeld, T., Bucsbaum, H., Herzlinger, G., Golan, S., Chilf, T., Eizenberg, H., Dor, E., and Kleifeld, Y. 1998. Orobanche aegyptiaca control in tomato fields with sulfonylurea herbicides. Weed Res. 38:343-349.

Holm, L., Doll, J., Holm, E., Pancho, J., and Herberger, J. 1977. Page 1129 in: Worlds Weeds: Natural Histories and Distribution. Wiley, New York.

Hosseini, P., Ahmadvand, G., Oveisi, M., Morshedi, P., and Gonzalez-Adugar, J. L. 2017. A modelling approach for predicting the initial phase of Egyptian broomrape (Phelipanche aegyptiaca) parasitism in potato. Crop Prot. 100: 51-56.

Joel, D. M. 2009. The new nomenclature of Orobanche and Phelipanche. Weed Res. 49:6-7.

Joel, D. M. 2013. The haustorium and life cycles of the parasitic Orobanchaceae. Pages 21-23 in: Parasitic Orobanchaceae: Parasitic Mechanisms and Control Strategies. D. M. Joel, J. Gressel, and L. J. Musselman, eds. Springer Verlag, Berlin, Heidelberg.

Kalivas, D. P., Vlachos, C. E., Economou, G., and Dimou, P. 2012. Regional mapping of perennial weeds in cotton with the use of geostatistics. Weed Sci. 60:233-243.

Kleifeld, Y., Golan, S., Graph, S., and Joel, D. M. 1987. Application of methyl bromide in heavy soils for broomrape eradication. Phytoparasitica 16:378.
Kuijt, J. 1977. Haustoria of phanerogamic parasites. Annu. Rev. Phytopathol. 15 91-118.

Little, D. L., and Shaner, D. L. 1991. Absorption and translocation of the imidazolinone herbicides. Pages 53-69 in: The Imidazolinone Herbicides. D. L. Shaner and S. L. O'Connor, eds. CRC, Boca Raton, FL.

Mesa-García, J., and García-Torres, L. 1986. Effect of planting date on parasitism of broadbean (Vicia faba) by crenate broomrape (Orobanche crenata). Weed Sci. 34:544-550.

Musselman, L. J. 1980. The biology of Striga, Orobanche and other parasitic weeds. Annu. Rev. Phytopathol. 18:463-489.

Parker, C. 2013. The parasitic weeds of the Orobanchaceae. Pages 313-344 in: Parasitic Orobanchaceae: Parasitic Mechanisms and Control Strategies. D. M. Joel, J. Gressel, and L. J. Musselman, eds. Springer Verlag, Berlin, Heidelberg.

Parker, C., and Riches, C. R. 1993. Page 332 in: Parasitic Weeds of the World: Biology and Control. Cab International, Wallingford, U.K.

Pérez-de-Luque, A., Florandes, F., and Rubiales, D. 2016. Differences in crenate broomrape parasitism dynamics on three legume crops using a thermal time model. Front. Plant Sci. 7:1910.

Pérez-de-Luque, A., Rubiales, D., Cubero, J. S., Press, M. C., Scholes, J., Yoneyama, K., Takeutchi, Y., Plalkhine, D., and Joel, D. M. 2005. Interaction between Orobanche crenata and its host: unsuccessful haustorial penetration and necrosis of the developing parasite. Ann. Bot. 95:935-942.

Pieterse, A. H. 1979. The broomrapes (Orobanchaceae) - a review. Abst Trop. Agric. 5:9-35.

Ran, F. A., Hsu, P. D., Wright, J., Agarwala, V., Scott, D. A., and Zhang, F. 2013 Genome engineering using the CRISPR-Cas9 system. Nat. Protoc. 8:2281-2308.

Schneeweiss, G. M., Colwell, A., Park, J. M., Jang, C. G., and Stuessy, T. F. 2004 Phylogeny of holoparasitic Orobanche (Orobanchaceae) inferred from nuclear ITS-sequences. Mol. Phylogenet. Evol. 30:465-478.

Screpanti, C., Yoneyama, K., and Bouwmeester, H. J. 2016. Strigolactones and parasitic weed management 50 years after the discovery of the first natural strigolactone strigol: status and outlook. Pest Manag. Sci. 72:2013-2015.

Westwood, J. H., dePamphilis, C. W., Das, M., Fernández-Aparicio, M., Honaas, L. A., and Timko, M. P. 2012. The parasitic plant genome project: new tools for understanding the biology of Orobanche and Striga. Weed Sci. 60:295-306.

Yaacoby, T., Goldwasser, Y., Paporish, A., and Rubin, B. 2015. Germination of Phelipanche aegyptiaca and Cuscuta campestris seeds in composted farm manure. Crop Prot. 72:76-82.

Yoneyama, K., Ruyter-Spira, C., and Bouwmeester, H. 2013. Induction of germination. Pages 167-194 in: Parasitic Orobanchaceae: Parasitic Mechanisms and Control Strategies. D. M. Joel, J. Gressel, and L. J. Musselman, eds. Springer Verlag, Berlin, Heidelberg.

Zwanenburg, B., and Pospísili, T. 2013. Structure and activity of strigolactones: new plant hormones with a rich future. Mol. Plant 6:38-62. 